\title{
Formula Jamu Antihipertensi and captopril are equally effective in patients with hypertension
}

\author{
Atina Hussaana*, Hadi Sarosa**, Ulfah Dian Indrayani***, Chodidjah', \\ Bagas Widiyanto*, and Danis Pertiwi ${ }^{*}$
}

\begin{abstract}
\section{BACKGROUND}

Hypertension is the main cause of morbidity and mortality associated with cardiovascular diseases. Many herbs/spices appear to have significant effects in favorably modulating high blood pressure. A jamu formulation containing 6 plant extracts, Formula Jamu Antihipertensi (FJA), has been described previously. This research study aimed to evaluate the effect of FJA as antihypertensive agent in mild to moderate hypertensive patients.

\section{METHODS}

This double-blind experimental study was conducted in 40 hypertensive patients, who were randomized into two groups. The first group was treated with oral administration of $2 \mathrm{~g} \mathrm{FJA}$ and the second group $25 \mathrm{mg}$ captopril daily for 4 weeks. Systolic and diastolic blood pressure as well as liver and kidney function were followed up every week. Independent$t$ test and two-way ANOVA were used to analyze the data with a level of significance of 0.05 .
\end{abstract}

\section{RESULTS}

The results showed that after the treatment, FJA and captopril were capable of significantly decreasing systolic and diastolic blood pressure $(\mathrm{p}<0.05)$. The decrease in systolic blood pressure between the two groups was identical ( $p>0.05)$, while the decrease in diastolic blood pressure was greater in the FJA group than in the captopril group ( $\mathrm{p}<0.05)$.

\section{CONCLUSION}

From this study it may be concluded that administration of FJA for 4 weeks is equally effective as captopril in reducing systolic and diastolic blood pressure in patients with mild and moderate hypertension. Thus, natural plants and herbs can be our source of drugs, with fewer side effects and better bioavailability for treatment of hypertension in the future.
*Department of Pharmacology, Faculty of Medicine, Sultan Agung Islamic University **Department of Physiology, Faculty of Medicine, Sultan Agung Islamic University ***Department of Histology, Faculty of Medicine, Sultan Agung Islamic University Department of Anatomy,

Faculty of Medicine, Sultan Agung Islamic University Department of Clinical Pathology, Faculty of Medicine, Sultan Agung Islamic University

\section{Correspondence :}

Dr. Atina Hussaana, MSi. Apt. Department of Pharmacology,

Faculty of Medicine, Sultan Agung Islamic University Jl.Raya Kaligawe Km.4, Semarang, Jawa Tengah Email: atinahussaana@unissula.ac.id

Univ Med 2016;35:81-8 DOI: 10.18051/UnivMed.2016.v35.81-88 pISSN: 1907-3062 / eISSN: 2407-2230

This open access article is distributed under a Creative Commons Attribution-Non Commercial-Share Alike 4.0 International License

Keywords: Јати, antihypertensives, captopril, hypertension patients 


\section{INTRODUCTION}

Efforts for the development and utilization of medicinal plants or traditional medications to treat various disorders, particularly degenerative diseases, is continuously attracting attention from the government, educational institutions, investigators, businessmen, and the community. The government, in this case the Ministry of Health, has issued guidelines for the utilization of herbal medications (jamu) at community healthcare facilities, namely that they shall meet the requirements of being safe, beneficial, and standardized. In addition, by Minister of Health Regulation (Permenkes) No. 003/Menkes/PER/ $\mathrm{I} / 2010,{ }^{(1)}$ the government provided a solution for the acceleration of jamu utilization in formal healthcare services through saintifikasi jamu (jamu "scientification") programs, which are healthcare-based clinical observational studies to provide scientific evidence for the properties of jamu. In spite of this, the results from those varied programs have not yet been capable of reaching the expected goals, namely the acceptance and use of traditional medications in formal healthcare services. Several factors are acting as constraints, such as the lack of scientific evidence in support of the efficacy and safety of the use of traditional medications.

The use of herbal medicine as a treatment modality has significantly increased over the last decade. ${ }^{(2)}$ This is due to several factors, the principal of which is that herbal medicine is a cheaper alternative with fewer undesired side effects. ${ }^{(3)}$ However, the increased desire to use herbal treatment is not a reflection of the economic status of an individual from a certain region or a country. Indeed, $70 \%$ of the population in developed nations have resorted to complementary and alternative medicine (CAM) for treatment purposes, and herbal medicine forms a large proportion of its application. ${ }^{(4)}$ As one of the efforts to overcome abovementioned constraints, a preliminary study was conducted to develop the formula jamu antihipertensi (FJA) [antihypertension herbal formulation] consisting of 6 medicinal plant extracts. The FJA comprises three blood pressure reducing components, i.e. the leaves of Apium graveolens L leaves (celery), ${ }^{(5,6)}$ Orthosiphon aristatus (Java tea, cat's whiskers, kumis kucing) (7) and Centella asiatica (Asiatic pennywort), ${ }^{(8)}$ and three components for improving physical fitness, i.e. the leaves of Phyllanthus niruri L. (meniran) ${ }^{(10)}$ and the rhizomes of temu lawak (Curcuma xanthorrhiza Roxb.) and turmeric (Curcuma domestica Val.). These six herbal components have been recommended by the National Commission for Scientification of Jamu (Komisi Nasional Saintifikasi Jamu). ${ }^{(11)}$ The herbal formulation using these six simplicia have been scientifically tested as to their clinical antihypertensive benefits. ${ }^{(12)}$ One study on hypertensive patients receiving antihypertension jamu, was capable of reducing systolic and diastolic blood pressure by $12.67 \%$ and $2.33 \%$, respectively, after 7 days of use. $^{(13)}$

From the results indicating the potential of FJA composed of the above six plant extracts, it was deemed necessary to conduct a further clinical study to determine the efficacy of FJA against patients with mild to moderate hypertension.

\section{METHODS}

\section{Design of the study}

This experimental study was designed as a double blind, randomized controlled trial. Oral FJA treatment was administered to patients with mild to moderate hypertension for one month, and compared with captopril. This study was carried out at the Faculty of Medicine, Sultan Agung Islamic University, Semarang, and the Sultan Agung Hospital, Semarang, from 2014 to 2015.

\section{Study sample}

Patients with mild to moderate hypertension were recruited from the environs of East Semarang. The minmal sample size was calculated with the following formula:

$$
2\left[\frac{(\mathrm{Z} \alpha+\mathrm{Z} \beta) \mathrm{SD}}{\mathrm{X}_{1}-\mathrm{X}_{2}}\right]=2\left[\frac{(1.96+1.96) 11.1}{10}\right]=8.7
$$


In this study, the sample size was taken as 40 persons meeting these inclusion criteria: diagnosed with mild to moderate hypertension ( systolic blood pressure $=140-180 \mathrm{mmHg}$, diastolic blood pressure $=90-109 \mathrm{mmHg}$, not consuming other drugs or herbals for study and clinical observation, and not suffering from other diseases. Exclusion criteria: having dyslipidemia and /or metabolic disorders.

\section{Interventions}

The Formula Jamu Antihipertensi (FJA) used in this study was made in capsule form. The FJA capsules consisted of extracts of Apium graveolens L, Orthosiphon aristatus, Centella asiatica, Phyllanthus niruri L., Curcuma xanthorrhiza Roxb. (temu lawak) and Curcuma domestica Val.(kunyit) rhizomes. The extracts used were standardized extracts of each of the plants, obtained from PT Industri Jamu Borobudur, Semarang. The standard hypertensive drug used as control was captopril $25 \mathrm{mg}$ in tablet form, which were then made into capsules.

\section{Administration of treatments}

Patients were block-randomized into two groups, i.e. one group receiving a dose of $2 \mathrm{~g}$ FJA and the second group receiving $25 \mathrm{mg}$ captopril daily. The treatment was administered daily in divided doses for 1 month. To ensure blinding of the treatment, the shape, color, size, and odor of the FJA and captopril capsules were made identical and placed in identical packaging containers with identical labeling. The treatment codes were applied to the packaging containers at a location not easily seen by the patients. The coding of the packaging containers, safekeeping of the code, and the random allocations were carried out by an investigator who did not examine the patients.

\section{Blood pressure measurements}

Blood pressure measurements in this study were performed before treatment and at the end of each week, using a mercury sphygmomanometer. The blood pressure of each patient was measured by three physicians, from whose results the mean blood pressure was calculated.

\section{Measurement of serum SGPT, SGOT, urea and creatinine concentrations}

To ensure blinding, the hepatic and renal function tests were done at the Sarana Medika clinical laboratory, Semarang. The urea concentration was determined using $2 \mu \mathrm{l}$ serum kwith the addition of $200 \mu \mathrm{l}$ BUN reagent (UreaKit $S$ 180) and incubated for 15 minutes. Absorbance was read at a wave length of 340 $\mathrm{nm}$. The normal urea concentration was taken as $7-21 \mathrm{mg} / \mathrm{dL}$.

The creatinine concentration was determined using $17 \mu \mathrm{l}$ serum with the addition of $150 \mu \mathrm{l}$ creatinine reagent (Creatinine liquicolor, Human) and incubated for 3 minutes. Absorbance was read at a wave length of 500 $\mathrm{nm}$. The normal creatinine concentration was taken as $0.5-1.3 \mathrm{mg} / \mathrm{dL}$. The serum glutamic pyruvic transaminase (SGPT) concentration was determined using $20 \mu \mathrm{l}$ serum with the addition of $200 \mu \mathrm{l}$ SGPT reagent (ALAT (GPT) FS, DiaSys Diagnostic Systems, Germany) and incubated for 10 minutes. Absorbance was read at a wave length of $340 \mathrm{~nm}$. The normal SGPT concentration was taken as $<31 \mathrm{U} / \mathrm{L}$. The serum glutamic oxaloacetic transaminase (SGOT) concentration was determined using $20 \mu \mathrm{l}$ serum with the addition of $200 \mu \mathrm{l}$ SGOT reagent (ASAT (GOT) FS, DiaSys Diagnostic Systems, Germany) and incubated for 10 minutes. Absorbance was read at a wave length of 340 $\mathrm{nm}$. The normal SGPT concentration was taken as $<32 \mathrm{U} / \mathrm{L}$.

\section{Ethical clearance}

This study was conducted after obtaining ethical clearance from the Ethics Committee, Faculty of Medicine, Sultan Agung Islamic University.

\section{Statistical analysis}

The independent t-test was used to draw conclusions as to mean differences in blood pressure between both treatment groups at 
baseline and at the end of the treatment. A twoway ANOVA was used to compare the mean differences of blood pressure between the treatment groups and duration of intervention. The significance level was fixed at 5\% level.

\section{RESULTS}

Forty patients with mild to moderate hypertension were involved in this study. During a follow-up period of 4 weeks, there were 6 dropouts for various reasons, such as typhoid fever necessitating ingestion of 5 medications, psychological reasons, and non-compliance in taking the treatment capsules. The flow of participants from recruitment until analysis is shown in Figure 1.

Of the 34 patients with mild to moderate hypertension participating in this study up to its completion, their characteristics in the two treatment groups are summarized in Table 1. Table 1 shows that among the patients who participated in this study, the groups receiving the FJA and captopril interventions were dominated by female patients aged 50 years or above. There were no significant differences between the patients in the FJA group and the captopril group. This indicates that the randomization was successful in distributing the other variables between the two treatment groups, apart from the treatment variables.

The results of systolic and diastolic blood pressure measurements of the participating patients with mild baseline hypertension during the first three weeks of follow-up and at the completion of the treatment in the fourth week, are illustrated in Figure 2. Mean systolic and diastolic blood pressure of the participants at the start of the study (baseline) did not differ between the FJA and captopril treatment groups. Both interventions equally reduced the systolic and diastolic blood pressure. After receiving the interventions for 4 weeks, both treatment groups showed significant differences in systolic and diastolic blood pressure $(\mathrm{p}<0.05)$ (Figure 2).

The two-way ANOVA results indicated that there was no significant interaction between treatment groups and duration of treatment for systolic blood pressure $(\mathrm{p}=0.066)$. However, there was a significant interaction between

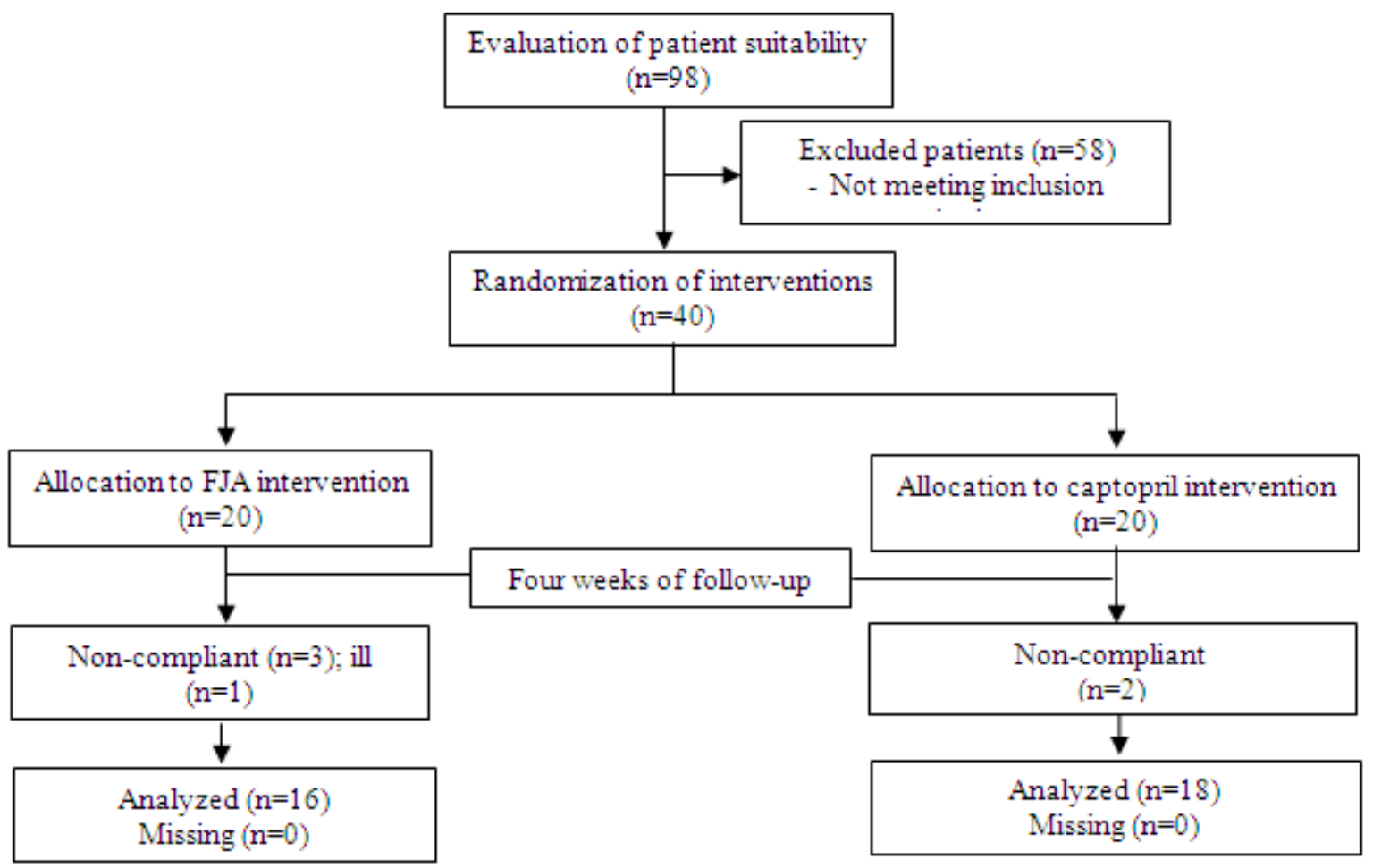

Figure 1. Flow of participants in Formula Jamu Antihipertensi clinical trial 
Table 1. Distribution of the characteristics of several variables, by treatment group at base-line

\begin{tabular}{|c|c|c|c|}
\hline Characteristi & FJA $(n=16)$ & Cap top ril $(n=18)$ & p \\
\hline $\begin{array}{c}\text { Age (years) } \\
<50\end{array}$ & $\begin{array}{l}53.3 \pm 8.2 \\
6(37.5 \%)\end{array}$ & $\begin{array}{l}51.3 \pm 5.5 \\
5(27.8 \%)\end{array}$ & 0.424 \\
\hline $\begin{array}{l}\text { Gender } \\
\text { Female }\end{array}$ & $12(75.0 \%)$ & $17(94.4 \%)$ & 0.318 \\
\hline $\begin{array}{c}\text { Syst olic BP (m mH g) } \\
140-159 \mathrm{~mm} \mathrm{Hg} \\
>160 \mathrm{~mm} \mathrm{Hg}\end{array}$ & $\begin{array}{l}9(56.2 \%) \\
7(43.8 \%)\end{array}$ & $\begin{array}{c}8(44.4 \%) \\
10(55.6 \%)\end{array}$ & 0.952 \\
\hline Diastolic BP & & & \\
\hline $\begin{array}{l}90-99 \mathrm{~mm} \mathrm{Hg} \\
>100 \mathrm{~mm} \mathrm{Hg}\end{array}$ & $\begin{array}{l}9(56.2 \%) \\
7(43.8 \%)\end{array}$ & $\begin{array}{c}15(83.3 \%) \\
3(16.7 \%)\end{array}$ & 0.154 \\
\hline Urea $(\mathrm{mg} / \mathrm{dL})$ & $21.0 \pm 5.0$ & $15.0 \pm 5.1$ & 0.064 \\
\hline Creatirine (m $g / d L)$ & $1.0 \pm 0.1$ & $1.1 \pm 0.2$ & 0.104 \\
\hline SGPT (U/L) & $18.1 \pm 10.0$ & $18.0 \pm 7.1$ & 0.213 \\
\hline SGOT (U/L) & $17.0 \pm 5.0$ & $19.0 \pm 5.7$ & 0.778 \\
\hline
\end{tabular}

FJA = formula jamu Antihipertensi; Normal urea = 7-21 mg/dL; Normal creatinine= 0.5-1.3 mg/dL; Normal serum glutamic pyruvic transaminase (SGPT) <41 U/L; Normal serum glutamic oxaloacetic transaminase (SGOT) $<32 \mathrm{U} / \mathrm{L}$

treatment groups and duration of treatment for diastolic blood pressure $(\mathrm{p}=0.015)$. The significant difference was between 1 week versus 2 weeks of treatment $(\mathrm{p}=0.006)$ and between 1 week versus 3 weeks of treatment $(\mathrm{p}=0.000)$ (Table 2).

There was no difference in mean serum SGOT, SGPT, urea and creatinine concentrations at baseline. The measurements were repeated at the end of treatment in the fourth week. These are presented in Table 3, showing that at the end of treatment, the urea, creatinine and SGPT levels did not differ significantly between the FJA and captopril groups. On the other hand, the final SGOT concentration in the FJA group was significantly higher than in the captopril group, although the increased SGOT concentration was still within the normal range (Table 3).

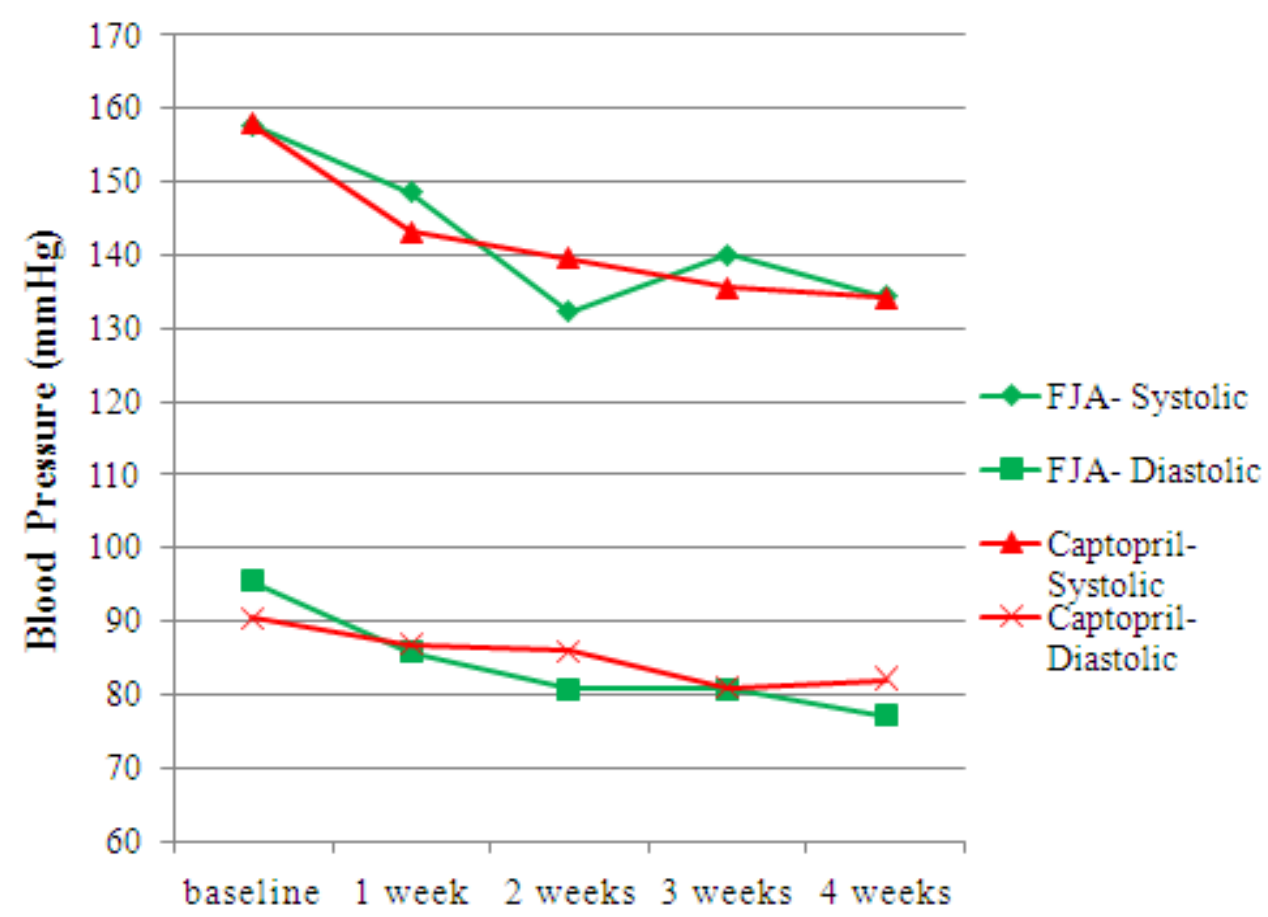

Figure 2. Mean systolic and diastolic blood pressure of patients with mild baseline hypertension, during follow-up and at the completion of the Formula Jamu Antihipertensi (FJA) treatment for 4 weeks 
Table 2. Comparison of mean systolic and diastolic blood pressures after 1,2, 3 and 4 weeks of treatment, by treatment group

\begin{tabular}{|c|c|c|c|c|c|c|c|c|c|}
\hline & \multicolumn{8}{|c|}{ Treatment } & \multirow[b]{2}{*}{$\mathbf{p}$} \\
\hline & $\begin{array}{c}\text { FJAl } \\
(n=16)\end{array}$ & $\begin{array}{c}\mathrm{Cl} \\
(\mathrm{n}=18)\end{array}$ & $\begin{array}{l}\text { FJA } 2 \\
(n=16)\end{array}$ & $\begin{array}{c}C 2 \\
(\mathrm{H}=18)\end{array}$ & $\begin{array}{c}\text { FJA3 } \\
(n=16)\end{array}$ & $\begin{array}{c}\text { C3 } \\
(n=18)\end{array}$ & $\begin{array}{c}\text { FJA4 } \\
(n=16)\end{array}$ & $\begin{array}{c}\mathrm{C4} \\
(\mathrm{n}=18)\end{array}$ & \\
\hline $\mathrm{SBP} m \mathrm{~m} \mathrm{Hg}$ & $\begin{array}{c}152.9 \pm \\
18.0\end{array}$ & $\begin{array}{c}1460 \pm \\
15.4\end{array}$ & $\begin{array}{c}132.3 \pm \\
12.5\end{array}$ & $\begin{array}{c}139.6 \pm \\
17.5\end{array}$ & $\begin{array}{c}133.5 \pm \\
16.2\end{array}$ & $\begin{array}{c}135.9 \pm \\
158\end{array}$ & $\begin{array}{c}146.7 \pm \\
19.9\end{array}$ & $\begin{array}{c}1348 \pm \\
13.8\end{array}$ & 0.066 \\
\hline $\mathrm{DBP} m \mathrm{mHg}$ & $\begin{array}{c}93.6 \pm \\
11.9\end{array}$ & $\begin{array}{c}88.1 \pm \\
7.1\end{array}$ & $\begin{array}{c}80.8 \pm \\
3.9\end{array}$ & $\begin{array}{c}86.0 \pm \\
8.2\end{array}$ & $\begin{array}{c}81.4 \pm \\
4.9\end{array}$ & $\begin{array}{c}81.6 \pm \\
5.6\end{array}$ & $\begin{array}{c}89.8 \pm \\
14.9\end{array}$ & $\begin{array}{c}82.4 \pm \\
8.1\end{array}$ & 0.015 \\
\hline
\end{tabular}

$\mathrm{SBP}=$ systolic blood pressure; $\mathrm{DBP}=$ diastolic blood pressure; FJA1 = Formula Jamu Antihipertensi after 1 week of treatment; $\mathrm{C} 1=$ captopril after 1 week of treatment; FJA2= Formula Jamu Antihipertensi after 2 weeks of treatment; $22=$ captopril after 2 weeks of treatment; FJA3= Formula Jamu Antihipertensi after 3 weeks of treatment; C3= captopril after 3 weeks of treatment; FJA4=Formula Jamu Antihipertensi after 4 weeks of treatment; C4= captopril after 4 weeks of treatment

\section{DISCUSSION}

The results of this study constitute evidence that FJA has an antihypertensive effect comparable with that of captopril. FJA could reduce the systolic blood pressure to an equal extent as did captopril and could even more effectively reduce the diastolic blood pressure than captopril. These results are in accord with those of the Saintifikasi Jamu Antihipertensi (SJA) study using the same 6 plant simplicia as FJA. These "scientification" results also proved that SJA can more effectively reduce the blood pressure as compared with captopril, although the difference is not significant. ${ }^{(13)}$

The combination used in FJA comprises herbal extracts acting on the target organs and herbals capable of improving fitness. The herbals affecting the cardiovascular system in this formulation are Apium graveolens L, Orthosiphon aristatus, and Centella asiatica. Other herbals in the formulation are Phyllanthus niruri L, Curcuma xanthorrhiza Roxb and
Curcuma domestica Val, which are expected to improve fitness, thus indirectly affecting the blood pressure.

The effects of FJA are the synergistic effects of Apium graveolens L, Orthosiphon aristatus, and Centella asiatica. Apium graveolens L has been demonstrated to have hypotensive, negative inotropic and chronotropic effects through stimulation of muscarinic receptors. ${ }^{(14)}$ The apigenin contained in Apium graveolens $\mathrm{L}$ has vasodilator and diuretic effects by decreasing the sodium stores of the body, thus reducing blood volume and cardiac output. ${ }^{(15)}$ Orthosiphon aristatus is capable of inhibiting the activity of angiotensin converting enzyme (ACE). ${ }^{(16)} O$. aristatus also contains potassium which can increase renal flow and sodium excretion, so that the blood pressure decreases. ${ }^{(17)}$ The hypotensive effect of Centella asiatica is the result of its triterpenoid content, which affects the reninangiotensin-aldosterone system (RAAS) and inhibits ACE and vasoconstriction . ${ }^{(18)}$ The active principles of the herbals Apium graveolens L,

Table 3 . Mean urea, creatinine, SGPT and SGOT concentrations after 4 weeks of treatment, by treatment group

\begin{tabular}{lccc}
\hline & FJA $(\mathbf{n}=\mathbf{l 6})$ & Cap topril $(\mathbf{n = 2 5 4})$ & p \\
\hline Urea (mg/dL) & $17.0 \pm 2.0$ & $15.0 \pm 2.3$ & 0.066 \\
Creatirine (m g/dL) & $1.1 \pm 0.1$ & $1.0 \pm 0.1$ & 0.242 \\
SGPT (U/L) & $20.1 \pm 11.1$ & $18.0 \pm 7.0$ & 0.632 \\
SGOT (U/L) & $23.0 \pm 7.0$ & $17.0 \pm 4.5$ & 0.017 \\
\hline
\end{tabular}

Normal urea $=7-21 \mathrm{mg} / \mathrm{dL}$; Normal creatinine= 0.5-1.3 mg/dL; Normal serum glutamic pyruvic transaminase $(\mathrm{SGPT})<$ $41 \mathrm{U} / \mathrm{L}$; Normal serum glutamic oxaloacetic transaminase SGOT) $<32 \mathrm{U} / \mathrm{L}$ 
Orthosiphon aristatus, and Centella asiatica that are responsible for inhibiting ACE activity are the flavonoids. ${ }^{(19)}$

As a whole, the plant extracts in FJA act synergistically in reducing blood pressure through a combination of vascular smooth muscle relaxation and muscarinic receptor stimulation, which mediate the endothelial release of relaxing factors, inhibition of influx and utilization of extracellular calcium ions by vascular smooth muscle, and attenuation of the force and degree of myocardial contractions, and through a diuretic effect.

The three other extracts contained in FJA, i.e. Phyllanthus niruri L, Curcuma xanthorrhiza Roxb and Curcuma domestica Val. are potential analgetic anti-inflammatory immunomodulators (AAI). The effect of Curcuma xanthorrhiza Roxb is to confer physical fitness, accelerate metabolism and improve liver function, Curcuma domestica stimulates digestion, while Phyllanthus niruri L improves the body defenses. ${ }^{(20)}$

The results of this study also showed that FJA did not disturb hepatic and renal functions. This may be because the active principles of Curcuma domestica Val. and Curcuma xanthorrhiza Roxb are curcuminoids that are active antioxidant, anti-inflammatory and hepatoprotective compounds. ${ }^{(21)}$ Similarly the active quercetin flavonoid content of Phyllanthus niruri $\mathrm{L}$ has antioxidant and hepato-protective effects. ${ }^{(22,23)}$

A large percentage of hypertensive patients are certainly treatable by appropriate adaptation of life-style changes, such as a shift from a sedentary (couch potato) setting to a more active, exercise-orientated healthy lifestyle. In addition to the above, ingestion/consumption of functionally bioactive nutrients, such as the aforementioned phenolic-rich and other botanical-derived pharmacological agents, would be beneficial to normal health. ${ }^{(24)}$ Therefore, such judicious modifications will not only ameliorate hypertension, but simultaneously diminish the onset of atherothrombogenic diseases (coronary arterial disease, peripheral arterial, and cerebrovascular diseases). Moreover, the burden on scarce national health budgets will decrease.

This study found no increase in body fitness or health status of the patients treated with FJA. On average, during the course of this study, the patients registered no complaints in relation to adverse or other uncomfortable effects of the administered treatment. The results of this study may add to the body of evidence regarding the actions and safety of FJA, so that this preparation may be administered to patients with mild to moderate hypertension. However, this study suffered from many limitations including the short duration of treatment and the sample participants were relatively small.

\section{CONCLUSIONS}

From this study it may be concluded that administration of FJA for 4 weeks is equally effective as captopril in reducing systolic and diastolic blood pressure in patients with mild and moderate hypertension. Thus, natural plants and herbs can be our source of drugs, with fewer side effects and better bioavailability for treatment of hypertension in the future.

\section{CONFLICT OF INTEREST}

The investigators had no conflicting interests in this study.

\section{ACKNOWLEDGEMENTS}

Thanks are due to the Directorate for Guidance of Research and Community Service (Direktorat Pembinaan Penelitian dan Pengabdian kepada Masyarakat, Dirbinlitabmas) of the Directorate General of Higher Education (Ditjen Dikti) for the funding of this study through a grant from the Higher Education Quality Research (Penelitian Unggulan Perguruan Tinggi, PUPT) fund for the year 2015. 


\section{REFERENCES}

1. Kementerian Kesehatan RI. Peraturan Menteri Kesehatan Republik Indonesia Nomor 003/ MENKES/PER/2010 tentang saintifikasi jamu dalam penelitian berbasis pelayanan kesehatan. Jakarta; 2010.

2. Frishman WH, Beravol P, Carosella C. Alternative and complementary medicine for preventing and treating cardiovascular disease. Dis Mon 2009;55:121-92. doi: 10.1016/ j.disamonth.2008.12.002.

3. Susalit E, Agus N, Effendi I, et al. Olive (Olea europaea) leaf extract effective in patients with stage-1 hypertension: comparison with captopril. Phytomedicine 2001;18:251-8. doi: 10.1016/ j.phymed.2010.08.016.4.

4. World Health Organization. Traditional medicine. Geneva: World Health Organization. Fact Sheet No 134;2008.

5. Vergara-Galicia J, Jimenez-Ramirez LÁ, TunSuarez A, et al. Vasorelaxant activity of extracts obtained from Apium graveolens: possible source for vasorelaxant molecules isolation with potential antihypertensive effect. Asian Pac J Trop Biomed 2013;3:776-9.

6. Moghadam AM, Imenshahidi M, Mohajeri SA. Antihypertensive effect of celery seed on rat blood pressure in chronic administration. J Med Food 2013;16:558-63.

7. Manshor NM, Dewa A, Asmawi MZ, et al. Vascular reactivity concerning Orthosiphon stamineus Benth-mediated antihypertensive in aortic rings of spontaneously hypertensive rats. Int J Vasc Med 2013, Article ID 456852, 8 pages http://dx.doi.org/10.1155/2013/456852.

8. Gohil KJ, Patel JA, Gajjar AK. Pharmacological review on Centella asiatica: a potential herbal cure-all. Indian J Pharm Sci 2010;72:546-56. doi:10.4103/0250-474X.78519.

9. Tabassum N, Ahmad F. Role of natural herbs in the treatment of hypertension. Pharmacogn Rev 2011;5:30-40. doi:10.4103/0973-7847.79097.

10. Bharati D, Rawat S, Sharma P, et al. Evaluation of in vivo efficacy of aqueous leaf extract of Phyllanthus niruri in diabetic hypertensive rats. Ann Clin Exp Hypertension 2015;3:1031-7.

11. Supriyatna, Moelyono MW, Iskandar Y, et al. Mengenal obat herbal pemahaman obat herbal untuk fitoterapi. Bandung: Unpad Pres;2013.

12. Ahmad AF. Analisis penggunaan jamu untuk pengobatan pada pasien di klinik jamu Hortus Medicus Tawangmangu.[tesis]. Jakarta: Universitas Indonesia; 2012.
13. Febriyanti RM, Maesaroh I, Supriyatna, et al. Analisis farmakoekonomi saintifikasi jamu antihipertensi, antihiperglikemia, antihiperkolesterolemia, dan antihiperurisemia. IJPST 2014;1:39-46.

14. Brankovic S, Kitic D, Radenkovic M, et al. Hypotensive and cardioinhibotory effects of the aqueous and ethanol extracts of Celery (Apium graveolens, Apiaceae). Acta Medica Medianae 2010;49:13-6.

15. Zhang YH, Park YS, Kim TJ. Endotheliumdependent vasorelaxant and antiproliperative effects of apigenin. Gen Pharmacol 2002;35:3417.

16. Shafaei, Mun'im A, Lukmanto D, et al. Inhibition of angiotensin converting enzyme (ACE) activity by some Indonesia edible plants. IJPSR 2013;6:1054-9.

17. Adam Y, Somchit MN, Sulaiman MR, et al. Diuretic properties of Orthosiphon stamineus Benth. J Ethnopharmacol 2009;124:154-8.

18. Larson AJ, Adaramoye OA, Anjos RM, et al. Hypotensive and endothelium-independent vasorelaxant effects of methanolic extract from Centella asiatica in rats. $\mathrm{J}$ Ethnopharmacol 2012;124:457-62.

19. Iswantini D, Trisilawati $\mathrm{O}$, Rahminiwati $\mathrm{M}$, et al. Formula antihipertensi $(>60 \%)$ captoril dari bahan aktif flavonoid pegagan, tempuyung, kumis kucing dan sambiloto dan budidaya untuk meningkatkan kandungan flavonoid $(>1,5 \%)$. LPPM-IPB Darmaga;2010.

20. Siswoyo H. Formularium jamu untuk anti hipertensi, hiperglikemia, hiperurisemia, dan hiperkolestrolemia. Jakarta: Badan Penelitian dan Pengembangan Kesehatan Kementrian Kesehatan RI;2011.

21. Akram M, Shahab-Uddin, Ahmed A, et al. Curcuma longa and curcumin: a review article. Rom J Biol Plant Biol 2010;55:65-70.

22. Bhattacharjee R, Parames CS. Protein isolate from the herb, Phyllanthus niruri L. (Euphorbiaceae), plays hepatoprotective role against carbon tetrachloride induced liver damage via its antioxidant properties. Food Chem Toxicol 2007;45:817-26.

23. Harish R, Shivanandappa T. Antioxidant activity and hepatoprotective potential of Phyllanthus niruri. Food Chem 2006;95:180-5.

24. Anwar MA, Al Disi SS, Eid AH. Antihypertensive herbs and their mechanisms of action: part II. Front Pharmacol 2016;7:50. doi: 10.3389/fphar.2016.00050. 